CZU:81'373.612.2

https://doi.org/10.52505/filomod.2021.15.37

\title{
APORTUL SEMANTIC ȘI PRAGMATIC AL METAFOREI ÎN LINGVISTICĂ
}

\author{
NATALia ROTARI \\ Institutul de Filologie Română „B. P.-Hasdeu” al MEC
}

\begin{abstract}
Rezumat. Studiul de față propune o analiză a funcției semantice și pragmatice a metaforei lingvistice, raportate la teoria cognitivității, metafora fiind considerată o categorie cognitivă a gândirii. Mutațiile de sens, în procesul metaforizării, sunt realizate la nivelul psiholingvisticii prin forța emoțională a vorbitorului declanșată de evenimente sau sentimente, metaforele find create în limbaj prin expansiune sau atracție. Caracterul creativ și generativ al metaforelor lingvistice contribuie la diversitate semanticăa iar cunoașterea semnificatului facilitează înțelegerea procesului metaforic. Explicațiile de ordin pragmatic descriu mecanismele de funcționare a metaforei lingvistice, or, mecanismul metaforic este centrat pe relația dintre $A$ și $B$, adică $A$ și $B$ nu pot fi metafore de la sine, relația dintre ele este cea care le crează.
\end{abstract}

Cuvinte-cheie: Metafora, expansiune, semantică, pragmatică, funcție.

Abstract. The present study proposes an analysis of the semantic and pragmatic function of linguistic metaphor, related to the theory of cognition, the metaphor being considered a cognitive category of thinking. Mutations of meaning, in the process of metaphorization, are realized at the level of psycholinguistics through the emotional force of the speaker triggered by events or feelings, the metaphors being created in language through expansion or attraction. The creative and generative character of linguistic metaphors contributes to semantic diversity, and knowing the meaning facilitates the understanding of the metaphorical process. The pragmatic explanations describe the functioning mechanisms of the linguistic metaphor, or, the metaphorical mechanism is focused on the relationship between $A$ and $B$, ie $A$ and $B$ cannot be metaphors by themselves, the relationship between them is what creates them.

Keywords. Metaphor, expansion, semantics, pragmatics, function.

Limbajul este un produs al unui amplu proces cognitiv prin care sunt antrenate voința, gândirea, creativitatea și memoria. Grație schemelor cognitive, vorbitorul creează și utilizează involuntar în vocabularul său un amalgam de metafore. $\mathrm{Cu}$ ajutorul metaforelor, vorbitorul realizează un șir de operații mentale: categorisirea, conceptualizarea, cunoașterea și aprecierea lumii înconjurătoare. Proiecția metaforică este realizată nu doar la nivelul unor concepte, ci și asupra unor structuri conceptuale complexe (Будаев, 2014, p. 11). 
Conceptualizarea cognitivă a procesului metaforic are la bază ideea că metaforele nu sunt doar expresii lingvistice, ci și structuri conceptuale sau metafore conceptuale, uşor identificabile înainte de manifestarea acestora în limbaj (Faur, 2015, p. 340). Analiza lingvistică este dublată de analiza conceptuală și analiza comunicațională. Stabilirea conceptelor metaforice poate părea, totuși, complet independentă de expresia lingvistică, metafora fiind prezentă, mai întâi, în gând, apoi în cuvinte. În consecință, conceptele metaforice, prin care este valorificată experiența noastră, sunt compatibile cu zeci de expresii diferite, care le accentuează expresivitatea. Deplasarea problemei adevărului, de la cuvinte spre idee, garantează în același timp autonomia semnificației lingvistice a condițiilor de fapt sau a aderenței subiecților și independența relativă a adevărului în raport cu semanticul.

Citându-1 pe Max Black, lingvistul francez Éric Bordas explică funcționarea expresiei metaforice, din punctul de vedere cognitivistic, ca pe o triadă constituită din trei repere:

- termenul metaforic sau focusul, care reprezintă instrumentul interpretării;

- structura enunțiativă sau cadrul, în interiorul căreia se află semnificația;

- contextul utilizării, care dictează condițiile adecvate producerii mesajului (Bordas, 2003, p. 61).

Fiecare dintre aceste repere participă, etapizat, cu o funcție precisă, la realizarea interpretării metaforice. De aici putem desprinde câteva principii de bază ale metaforei, axate pe teoria relațională:

1. metafora nu este doar o expresie lingvistică particulară, însă implică planul enunțiativ (contextul);

2. metafora se caracterizează prin interacțiunea a două componente: focusul și cadrul;

3. între cele două componente există o relație de dependență funcțională;

4. semnificația (sensul și denotația) unei metafore rezultă din interacțiunea celor două componente, fiind de natură fundamental cognitivă.

Metafora nu este o descoperire/ creație pur lingvistică, ci o structură conceptuală prin care se valorizează o strategie de cunoaștere particulară, iar utilizarea unui domeniu-sursă familiar este conceput ca pe un model de categorisire a altui domeniu mai puțin explorat (Prandi, 2002, p. 8).

În ceea ce privește configurația structurală, un enunț metaforic conectează in praesentia un cadru, în concordanță cu structura enunțiativă care îl găzduiește, și un focus conceptual extraterestru. Interacțiunea metaforică, pe de altă parte, implică două subiecte ale discursului - un subiect primar pe care se bazează discursul și un subiect subsidiar care i se aplică.

În opinia lui Michele Prandi, metafora care are un substantiv într-o poziție predicativă este singurul tip în care conceptele implicate în metaforă sunt legate de o relație in praesentia. Dacă un substantiv este folosit într-o 
poziție referențială, subiectul principal nu coincide cu cadrul, ci cu referentul destinat focalizării, care nu are expresie lingvistică în enunț (Prandi, 2002, p. 12).

Metafora nu este capabilă doar să creeze expresie pentru structuri conceptuale independente și coerente, dar poate să construiască și conţinut complex antagonic, atrăgând termeni care se află în opoziție totală cu alți termeni, fie sunt din domenii diferite, fie fac parte din același câmp semantic. În prezența unor concepte incompatibile, relația dintre structurile conceptuale și formele lingvistice este inversată. Un concept incoerent nu poate fi justificat din interiorul conceptelor autonome, care sunt, prin definiție, coerente și, prin urmare, pot fi concepute doar ca pe un conținut al unei expresii cu proprietăți gramaticale specifice.

În enunțul: „Înainte de apariția medicinei moderne și a nenumăratelor posibilități diagnostice de azi, înainte de existența microscopului și a analizelor de laborator, ochiul examinatorului era vital în identificarea unei boli" (7), secvența scrisă cu italice este o expresie metaforică conceptuală, la baza căreia stau termeni de natură gramaticală identică, dar diferiți din punct de vedere semantic, analizați în mod separat. Substantivele ochiul, examinatorului, vital, boli fac parte din câmpul semantic al domeniului medicinei. Prin definiție, analizat semantic separat, substantivul vital semnifică „care aparține vieții, care este caracteristic sau esențial pentru viață, în care rezidă viața; de viață, al vieții” (5), termen care, semantic, este un pleonasm pentru lexemul ochi, or, acest organ este de la sine înțeles un organ vital, însă în expresia propusă vital este nume predicativ. Lexemul își pierde denotația proprie, expresivitatea fiindu-i amplificată de către verbul copulativ $a f i$. De aici, putem conchide că unele concepte sunt supuse jocului metaforic, schimbându-și proprietățile gramaticale și respectiv, pe cele semantice.

Conținutul metaforic nou este produs prin cartarea sau proiecția structurii schematic-imagistice a unui conținut experiențial de la domeniusursă la domeniu-țintă. Gândirea metaforică recurge la tiparele schematicimagistice ale experienței noastre preverbale. Lingvista Ana-Maria Trăntescu susține că dintre regulile de transfer semantic, regula transferului metaforic este mai vastă, deoarece are loc nu doar la nivelul substantivelor, ci și a altor părți de vorbire (Trăntescu, 2014, p. 190).

Prin metaforă, se extinde comprehensiunea unui concept definit printr-un domeniu semantic cunoscut la un concept nou definit printr-un domeniu semantic necunoscut (Gheorghișenco, 2019, p. 590). Metafora și analogia de proporție se întâlnesc exact la nivelul efectului de sens, la nivelul producerii de sens, instituind o nouă semnificație. Prin urmare, noțiunea abstractă poate fi considerată ca inovație de sens din momentul ce și-a iniţiat cursul metaforic. Dintr-un sens strict metaforic, prin 
lexicalizare, se ajunge la sens propriu, metaforicitatea producând o nouă normă a pertinenței semantice (Lengyel, 2016, p. 82).

Limbajul metaforic, prin inovația de sens, se constituie tot timpul ca o redescriere a lumii, un nou decupaj al lumii, proces care se realizează la nivel cognitiv prin intermediul a a două operații:

- evidențierea noilor referenți;

- determinarea exactă a trăsăturilor conceptuale ale realității.

Modificarea paradigmei științifice constituie o schimbare de viziune asupra lumii, fapt care contribuie la o altă interpretare diferită a datelor și a obiectelor din lumea înconjurătoare. Mecanismul metaforei se bazează tocmai pe faptul că sensurile denotative ale termenului figurat, existente în structura sa semantică, nu doar total: dimpotrivă, tocmai păstrarea lor este condiția indispensabilă a realizării abaterii manifestate, metasememice (Slave, 1991, p. 11).

Pentru explicarea structurii metaforice, se recurge adesea la categoria conotației, conotațiile fiind identificate ca elemente expresive, afective cu dublă natură: naturale, prin evocare. Menționăm că nu există conotații fără denotații pentru că cercetarea conotației implică aplicarea procedeelor proprii semantice. Conotațiile, legate de o trăsătură semică sau alta, impregnează întregul semem cu o anumită coloratură, adăugată la denotație. Structura semantică care se leagă de conotație nu se limitează doar la analiza semică și la relația cu referentul, cu obiectul. Noua semnificație a grupării de seme este supusă unor modificări dinamice determinate de factori din afara simplei structuri a semenului. De exemplu, lexemul pansament, conform Dicționarului Explicativ al Limbii Române este ,mijloc de protecție împotriva unei infecții și de tratare a unei boli prin aplicarea pe regiunea bolnavă a unor medicamente și acoperirea ei cu bandaje, vată etc." (4). Această definiție se află pe prima poziţie în dicționar, astfel accentuându-se ideea că articolul lexicografic, pe prima poziție, are explicațiile sensurilor proprii ale cuvintelor. În structura „Pentru vindecarea sufletului avem nevoie de un pansament"(6), lexemul pansament este utilizat cu sens metaforic, astfel are loc regruparea semelor într-o entitate nouă. Sinteza este rezultatul unui proces semantic, caracterizat printr-un dinamism evident. Contrastul contextual nu face decât să pună în lumină conotaţia.

În concluzie, putem menționa că procesul metaforic este în strânsă legătură cu procesele cognitive ale omului și situațiile contextuale în care nimerește. Ideea pe care o are omul se materializează prin intermediul metaforelor conceptuale pe care le utilizează în procesul exprimării. Imaginile cognitive se transformă în structuri lingvistice utilizate în contexte anumite, necesare pentru exprimarea gândurilor. Pragmatismul utilizării metaforelor cognitive contribuie la diversificarea semantică a termenilor în limbă, astfel asigurându-se o continuă diferențiere de sens. 


\section{Referințe bibliografice:}

1. BORDAS, Éric. Les chemins de la Métaphore. Paris: Presses Universitaires de France, 2003.

2. FAUR, Elena. Semantica cognitivă și „Teoria metaforei conceptuale”. O abordare din perspectivă integrală. În: Limba română, LXIII (3). București: Editura Academiei, 2015, pp. 340-356.

3. GHEORGHIȘENCO, Tatiana. Metafora ca un proces social de gândire cognitivă. În: Preocupări contemporane ale științelor socioumane. Ediția a X-a, 5-6 decembrie 2019. Chișinău, pp. 589-594.

4. https://dexonline.ro/definitie/pansament

5. https://dexonline.ro/definitie/vital

6. https://point.md/ru/novosti/nauka/sfaturi-de-la-psiholog-pentru-pate-cele8-reguli-ale-granielor-sufleteti/

7. https://www.viata-medicala.ro/na/utilizarea-metaforelor-in-medicina-14837

8. LENGYEL, Attila. Revoluțiile științifice și gândirea filosofică. Aportul de cunoaștere al metaforei. Brăila: Ed. Sfântul Ioan, 2016.

9. PRANDI, Michael. La métaphore: de la définition à la typologie. În: Langue française. Nouvelles approches de la métaphore, nr. 134. Paris: Larousse, 2002, pp. 6-20.

10. SLAVE, Elena. Metafor în limba română. Comentarii și aplicații. București: Editura Științifică, 1991.

11. TRĂNTESCU, Ana-Maria. Rolul proceselor de metaforizare în mutațiile de sens. În: Lexic comun/Lexic specializat, Fasc. 24/II.1(2), 2014, pp. 188-193. [online] Disponibil pe https://www.diacronia.ro/ro/indexing/details/A3370/pdf (accesat pe 19.09.2021)

12. БУДАЕВ, Эдуард В. Когнитивная теория метафоры: новые горизонты. În: Известия Уральского федерального университета. № 1 (110), 2013, p. 6-13.

Notă: Articolul a fost realizat în cadrul proiectului de cercetare 20.80009.1606.01 Valorificarea științifică a patrimoniului lingvistic național în contextul integrării europene, Institutul de Filologie Română „B. P.-Hasdeu” al MEC. 